\title{
TOURIST ATTRACTIVENESS OF THE POLISH BALTIC COAST HEALTH RESORTS
}

\author{
E. Rydz, P. Szmielińska-Pietraszek \\ Institute of Geography and Regional Studies \\ Pomeranian University in Stupsk \\ Stupsk, Poland
}

\begin{abstract}
Health resort treatment, which involves the use of the therapeutic properties of the climate or natural resources, has a long tradition in the world. Since earliest times numbers of patients travelled to places that have water treatment which is different from ordinary water through distinct taste, smell, and sometimes heat. Very popular were the places rich in thermal springs, not only for hygienic purposes, but mainly for rejuvenating.
\end{abstract}

Key words: tourist, tourist attractiveness, thermal springs.

Health resort treatment, which involves the use of the therapeutic properties of the climate or natural resources, has a long tradition in the world. Since earliest times numbers of patients travelled to places that have water treatment which is different from ordinary water through distinct taste, smell, and sometimes heat. Very popular were the places rich in thermal springs, not only for hygienic purposes, but mainly for rejuvenating. The particular contribution in the work of popularizing the bathing areas, put the Romans, because they built them along with amphitheaters and temples of the gods. The idea of the size of these buildings is given by the ruins of thermal baths of Caracalla on the Via Appia. The idea of the size of these buildings is presented by the ruins of thermal baths of Caracalla on the Via Appia. A passion for bathing was taken over by Muslims, Arabs and Turks, who have created a new type of bathhouse, called now "the Turkish" [10].

In Europe, the tradition of health resorts was continued, especially where hot baths were built for the Roman legions, or initiated by the newly discovered spring. Many of them, such as Aquae Calidae - today's Vichy France, Aquae Helveticae - that is - Baden in Switzerland and Aqua Herculi - now Baile Herculane in Romania and Aquae Solis - a contemporary Bath continues to function [28]. However, the first dated information about the medicinal use of the waters in the Polish lands, date from the mid thirteenth century and relate to today's Lądek Zdrój, but the first bathing facilities were built in the XVI XVII century. Development of subsequent health resorts occurred in the sixteenth and seventeenth centuries. Spas such as Kudowa Zdrój, Iwonicz Zdrój, Szkło and Swoszowice were built then. Therapeutic treatments in the form of baths were used there [2]. The first studies of spas in the Polish language originated in the Renaissance. The author of them is Wojciech Oczko considered the father of Polish spas, at the same time the court physician to the King Stefan Batory. In his works he mentioned the Iwonicz as a place indicated for the treatment of rheumatism and gout. He spoke also about Drużbaki and Swoszowice as spas. Another excellent doctor - Erasmus Sixtus, was delighted with Szkło, situated 
between Jarosław and Lviv, providing the way to use its mineral waters and mud baths..

Subsequent years brought a wider interest in other spas, that previously were known only to the local population. A classic example would be Krynica, that an Austrian officer Franz von Saunbergen Stix in 1793, identified as a health resort. Particularly famous, in the second half of the nineteenth century, thanks to the actions and activities of Jozef Dietl, a professor at the Jagiellonian University, the founder of scientific balneology and the reviver of the Carpathian health resorts. Zakopane has done a similar career; in 1873 Titus Chałubiński came and from that moment he became an ardent advocate of the city. During the half of a century, Zakopane became, at first, the summer capital city of Poland, and later the winter capital and exceeds the popularity of all spas and summer resorts. All those who, in those days, had something to say in Polish culture, science, politics, visited the place [10].

It should be emphasized, that the development of health resort treatment on a large scale, was initiated no sooner than in the eighteenth century. It was then, thanks to the economic development of many countries (especially England) and the growing prosperity specific social groups, trips to health resorts - "to mineral waters and mud baths" became very fashionable among the elite of societies all over Europe.

Also on Polish territory-as a consequence of the increasing promotion of balneological treatment and commonly used in Western European countries hydrotherapy, health resorts such as: Duszniki Zdroj Jedlina Zdroj Swieradow Zdroj Polanica Zdroj and Jelenia Gora started to develop. In addition to these health resorts in Lower Silesia, Busko Zdrój was also established with its famous springs, which for centuries were the property of a monastery, and with its own swimming facility. Krynica was also formed. At the same time (1836), due to saline graduation towers and salt works, Ciechocinek began its career. Specific curative seaside climate, resulted in increasing popularity of health resorts located in the coastal zone of the Baltic Sea including Świnoujście, Kamien Pomorski, Kołobrzeg and Sopot. Trips to the springs have become a part of the lifestyle of the era, especially those who were wealthy.

The nineteenth century was marked in Poland, not only increasing the number of residence health resorts but also by improving the ways of spa treatment. Due to vigorous activities of the medical community and Polish chemists, in this period, a number of research works has been created indicating the high value of domestic springs and introduce new methods of treatment (therapeutic mud, inhalation places). In 1905 in Cracow, the Polish Balneological Society was established. Its primary aim was to create the scientific and medical business foundations of health resorts.

After regaining the independence, despite the economic crises, there has been a rapid development of health resorts. In 1922 the first Polish health resort bill was issued, amended later in 1928. Druskienniki resort, a favorite resort of Marshal Jozef Pilsudski was extended along with Tryskawiec famous for medicinal water "Naftusia". Żegiestów became fashionable and Wisla that was visited by President Ignacy Moscicki. It should be noted that earlier the owners of spas, due to the initiative of Count Jan Potocki of Rymanów, founded in 1910, Association of Polish Health Resorts originally based in Lviv, then in Warsaw. Its activities, among other things encouraged the society for the treatment in the domestic spas. 
In the later period, the institutions such as Health Insurance Fund, Social Insurance Institution, began to affect the policies of health resort. The first sanatorium of Social Insurance Institution were created in Inowrocław, Krynica, Iwonicz and in the climatic health resorts - Zakopane, Otwock, Bystre. Health insurance fund has granted the insured people the therapies, including free medical care and necessary treatment, but the number of patients sent to the resorts at the expense of society at that time was insignificant, despite the enormous needs.

The Second World War brought enormous destruction of spa facilities. Sanatoria were used as hospitals and convalescent centers for the invader soldiers. The retreating German troops, and the upcoming Soviet army, often destroyed the therapeutic equipment and exported it, so after the war ended, many resorts began its activity in boarding houses without beds, with destroyed Natural Curing Facilities and a small staff of professionals.

As a result of shifting borders after World War II, on one side - on the lost eastern territories, the number of spas and climatic stations such as Druskienniki, Truskawiec, Morszyn, Niemirów, Jeremicze or Burkut were left. On the other hand, on the opposite side of the country, Poland has been enriched by popular resorts of Lower Silesia and Pomerania, which for centuries have been visited by our countrymen. A classic example of this may be numerous visits of prominent, well known Poles in coastal resorts such as Kossak family or Feliks Nowowiejski in Swinoujscie.

The basis for further organizational change was the nationalization of the base of the thermal treatment and the inclusion of the therapy in those facilities into the free health care system. A kind of a democratization of spas, which occurred after World War II, caused that among the patients' staying in health resorts for treatment, people from almost all social classes began to appear. This phenomenon can be described as "egalitarianism" in trips to health resorts [6]. "Trips to the waters' ceased to be, therefore, the privilege of the few social groups. A similar phenomenon, unpaid stays in health resorts, based on a medical referral, was also introduced in other countries of the Eastern bloc. This phenomenon, in Poland contributed to the development of health tourism, understood as a "change of permanent residence to stay in the climate with the task of improving the physical and mental health" - in particular through prevention and recreation [29]. Generally, the trips are therefore related to the sanatorium treatment, rehabilitation and spa healing, associated treatments with natural medicine, provided on the basis of consultation with the doctor in spa [4].

It should be noted that the peak the constructing of new spa buildings - built mainly from funds from the workplaces and trade unions, was continued especially in the 70's of last century. A good example, were very well developing resorts on the Polish Baltic coast, especially Kolobrzeg and Świnoujście as well as Kamien Pomorski. Later, there were some limitations in providing the social healthcare, that was a result, among other things, of the need to adjust the health resorts to the conditions of market economy. At the turn of 19981999, Państwowe Przedsiębiorstwa Uzdrowiskowe (the state-owned companies of the health resorts) were transformed into one-person companies of the Treasury. In light of the generally outlined issues, the principal aim of this paper is an attempt to show the tourist attractiveness of statutory health resorts, located on the Polish coast [1] The article focuses, among other things, natural and non-natural health resorts development factors, trends 
and therapeutic profiles conducted in spas, as well as Baltic health resorts participation in governing the provision of treatment services across the country. It was assumed that health resort treatment and health tourism have two principal areas of development. The first of them is human biological regeneration through the use of healing waters, natural mineral resources and climate characteristics. The second, are the active leisure activities (proximity to forest areas, sea water, and sports - recreational base).

\section{The natural conditions of spa tourism.}

Spa tourism in Poland is one of the main branded products aimed at the domestic and foreign markets. With rich natural values of medicinal properties, mineral springs, microclimate, etc., the Polish territory certainly stands out, in this regard, the high attractiveness and competitiveness compared to Europe. Polish geographical location makes the climate transitional - between marine and continental. It is characterized, therefore, a large variability in both temporal and spatial states of the weather. This is the main feature of the Polish climate, clearly indicating at the turn of winter and spring. This variability of climate and bioclimate, results from instability of the main the climateforming factors, including solar radiation, the movement of air masses, which is caused by pressure and temperature differences between land and sea. A major climate-forming factor is topography, distance from water reservoirs and plant community. It should be noted that the human body is subject to the unceasing action of the various elements of the atmospheric environment that shape the mood, feeling of heat, and even affect health conditions. Their action has a nature of the stimulus and is continuous in a comprehensive manner, with the intensity varying in time and space.

Given the climate-forming factors on Polish territory, we can distinguish six bioclimatic regions, differing in degree of weathering stimuli [9]. These are:

- The coastal region with a strong stimuli bioclimate, including the Baltic coast,

- Lake district region of mild climate stimuli,

- The North - East region (the coldest, except for the mountains) with a moderate stimuli bioclimate,

- The central region of weak stimulus bioclimate

- The South - East region, the warmest, with increased thermal stimuli,

- The foothill and mountain region (Carpathian and Sudeten Mountains) with a strong stimuli bioclimate.

It should be emphasized that the bioclimatic conditions of 44 Polish spas are also varied and depend not only on the region where they are, but also on local conditions such as topography, vegetation, and height above sea level. Generally, the Polish health resorts due to geographical location, can be divided into:

- Low-lying resorts, located 200 meters above level sea

- Seaside resorts, situated at a distance of not more than $3 \mathrm{~km}$ from the sea,

- Foothill resorts, situated between 200 and $400 \mathrm{~m}$ above sea level

Taking into account the geographic location, including altitude above sea level, the largest group constitute the low-lying resorts - 16 and foothill resorts - 14 (Table 1)

In the case of coastal health resorts, which are the subject of analysis, we can talk about a large stimuli of this bioclimate. Reasons for this are mainly strong winds, causing high 
values of biological cooling and the relatively high intensity of solar radiation at the turn of spring and summer. The coastal climate is shaped by the cool waters of the Baltic Sea, at $15^{\circ} \mathrm{C}$ at the beginning of the bathing season. A specific feature of the coast climate, is the presence of marine aerosol consisting of crystals of sea salt and iodine, which arises from the splashing waves.

Table 1. Division of Polish spas due to the geographical location

\begin{tabular}{|c|}
\hline Lowland health resorts \\
\hline $\begin{array}{l}\text { Augustów, Krasnobród, Busko Zdrój, Nałęczów, Ciechocinek, Połczyn Zdrój, Goczałkowice - Zdrój, } \\
\text { Gołdap, Solec - Zdrój, Horyniec - Zdrój, Supraśl, Inowrocław, Swoszowice, Konstancin - Jeziorna, } \\
\text { Wieniec -Zdrój, Przerzeczyn - Zdrój }\end{array}$ \\
\hline Seaside health resorts \\
\hline Kamień Pomorski, Świnoujście, Kołobrzeg, Ustka, Sopot, Dąbki \\
\hline Foothill health resorts \\
\hline $\begin{array}{l}\text { Cieplice - Zdrój, Piwniczna - Zdrój, Czerniawa Zdrój, Polanica - Zdrój, Długopole - Zdrój, Polańczyk, } \\
\text { Duszniki - Zdrój, Rymanów - Zdrój, Iwonicz - Zdrój, Szczawno - Zdrój, Kudowa - Zdrój, Ustron,, } \\
\text { Muszyna, Wapienne }\end{array}$ \\
\hline Mountain health resorts \\
\hline $\begin{array}{l}\text { Jedlina - Zdrój, Szczawnica, Krynica - Zdrój, Lądek - Zdrój, Wysowa - Zdrój, Rabka - Zdrój, } \\
\text { Żegiestów, Świeradów - Zdrój }\end{array}$ \\
\hline
\end{tabular}

Source: Health resort treatment in Poland in the years 2000 - 2010. Information and statistical studiepp. Central Statistical Office, Statistical Office in Krakow, Krakow 2011, own elaboration

The average content of sodium chloride on the beach varies from 1.1 to $45 \mu \mathrm{g} / \mathrm{m}^{3}$. The optimal conditions for the natural inhalation of sea spray occurs when the wind blows from the sea and in case of fog, while its amount in the air decreases together with the distance from the coast [8]. Having medicinal properties, sea spray settles on the mucous membranes of the upper respiratory tract, salt particles reach the alveoli to reach the bloodstream in them. Influenced by the marine aerosol, lung capacity increases, which is important for children. These properties have played a large role in the location of health resorts for children, among others, in Kołobrzeg and Dąbki. Aerosol settling on the skin reduces inflammation and allergic reactions. Iodine, which is found in marine aerosols, affects the thyroid gland.

A characteristic feature of the climate of the coast is also the presence of winds of the type of breeze. These winds are caused by the different warming of the land and the surface of the water throughout the day and night. The daily sea breeze blows up from a cooler sea onto the hot land, while the night breeze is opposite - from very quickly cooling down land towards the warmer sea.

The significant influence on the healing properties of the coastal zone climat is exerted by the occurrence of the large forest complexes. The most important bioclimatic role of forests, lies in the presence of air of very good hygienic conditions. Woods absorb dust and gas pollution, reduces noise and enriches the air with flavoring substances. Not without significance is the impact of forests on the human psyche because of the calming effect of green. 
From the bio-climatic point of view, very important is the production and secretion, by many plants, so called phytoncides - volatile substances (essential oils) with a germicidal and fungicidal properties. They are secreted by pine, larch, linden, oak and juniper. As a side note, it should be noted that, in case of a Baltic coastal zone, the most commonly occurring is a pine, having significant medicinal properties. Indisputable advantages of coastal health resorts, is therefore a treatment with factors related to climate and sea water. Thalassotherapy (from the Greek Thalassa - Sea), defining the therapeutic impact of marine climate, has already been well known in ancient Greece. While bathing, sunbathing on the beach or walking by the sea, more or less consciously we are strengthening our health. Hardening of the organism in sea water baths and air baths in the marine atmosphere, we make it less prone to sudden changes in the ambient temperature, and by the sensible sunbathing we are additionally strengthening its defense mechanism. These thalassotherapy treatments, spontaneously made by holidaymakers, only in modern times acquired - just like the entire physiotherapy - a scientific foundation. Medical observation deepened by clinical studies have shown the high usefulness of the sea and the climate as the treatment for several chronic diseases [24]. In many coastal towns, that were bathing resorts, on the basis of existing natural materials, statutory spa was established. Treatment units were opened in the villages, which also carry the treatment of certain diseases but do not have the status of the spa.

The available materials indicate that thalassotherapy in the Polish territories has a rich tradition, as the first swimming pools were created at the beginning of the nineteenth century: Kołobrzeg (1803), Sopot (1823), Świnoujście (1824), Ustka (1835), Krynica Morska (1840), Sarbinowo (1842). Many of them have long been recognized health resorts. Polish coast, with a length of $524 \mathrm{~km}$, has excellent climatic conditions and offer better and better organizational conditions for rest, treatment and rehabilitation, that meets the conditions for widely understood health tourism. Here also are located six statutory spas, recognized and appreciated not only in Poland but in many European countries: Świnoujscie, Kamień Pomorski, Kołobrzeg, Dąbki, Ustka and Sopot as well as eight towns with specific health resorts rights (Fig. 1). They are: Dziwnów, Dźwirzyno, Jastarnia, Jurata, Krynica Morska, Łeba, Łukęcin and Międzywodzie [11].

It should be noted that these towns especially those in which spas are registered, have well known medicinal waters from their own sources as well as deposits of mud. At these spas, besides thalassotherapy, other methods of modern physical therapy are also used - mainly balneotherapy, including treatments in the mud baths and swimming in the medicinal mineral waters.

Great importance for the seaside health resort, has a chemical composition of sea water, its physical and biological characteristics as well as the climate. It should be noted that the characteristics of climate and sea water depends primarily on the geographic location and the size of the sea. The sea water is a variety of natural chloride - sodium mineral water. Its main components of cations are: sodium, potassium, magnesium, strontium, and of anions: chlorine, bromine, fluorine, sulfates and carbonates. Differences in the composition and intensity of the components depend on the sea. The salinity of sea water varies to some extent, depending on the season, depth and distance from shore. It also depends on amount of fresh river water flowing into it. The intensity of salt in the water in the Baltic Sea varies 
from $11 \%$ in the western part to about $3 \%$ in the eastern parts. In the area of the Polish coast it amounts about $7 \%$. Salinity, however, is significantly lower in comparison to the waters of the Adriatic Sea, which is $24-48 \%$, the Atlantic Ocean - 30-38 \%o, the North Sea

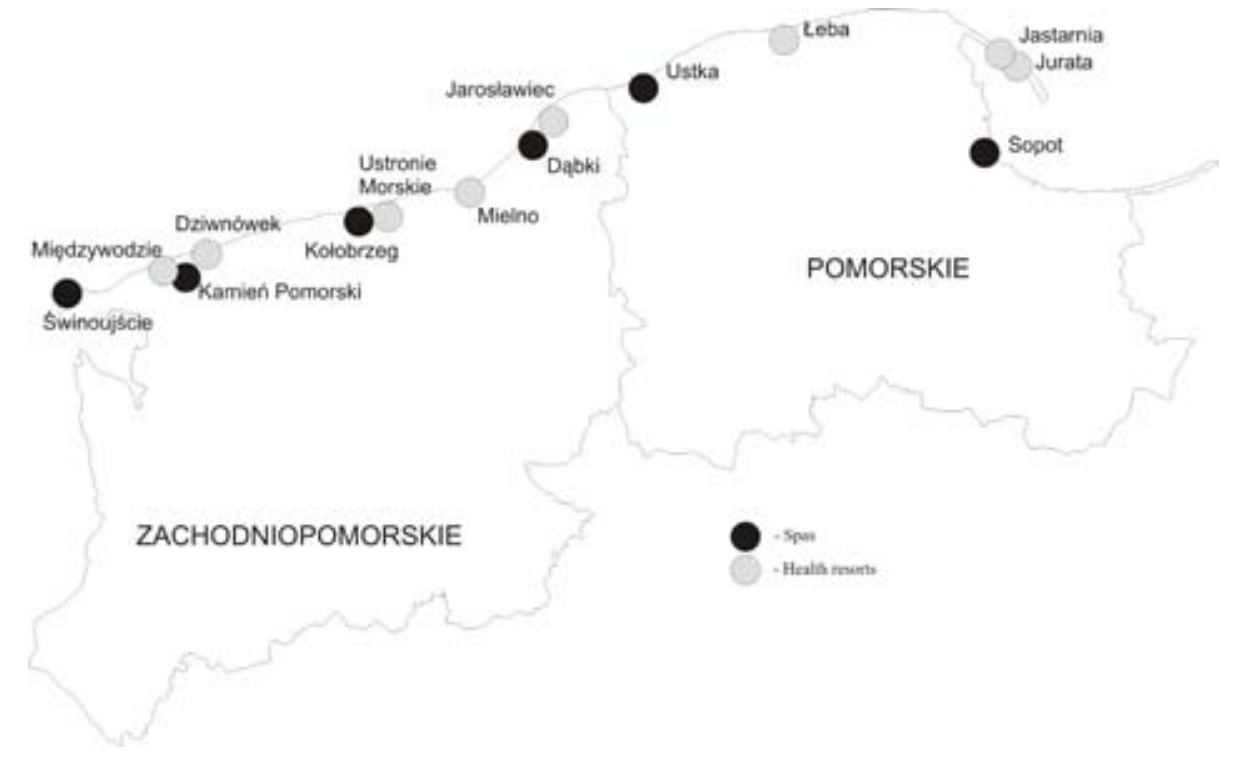

of approximately $33 \%$ or $17 \%$ of the Black Sea [23].

Figure 1. Spas and health resorts on the Polish coast of the Baltic Sea in 2010.

Source: Health resort treatment in Poland in the years 2000 - 2010. Information and statistical studiepp. Central Statistical Office, Statistical Office in Krakow, Krakow 2011

Hydrotherapy, with the use of mineral water are known to be strong stimulus treatments, and therefore require careful dosing. In determining the dosage of treatment factors like the patient's general health, his sensitivity to cold and heat, current neural excitability, resistance to cold sea baths, should be taken into account. The element of thalassotherapy is also heliotherapy - healing with the sun. The sunbathing should also be taken with caution and moderation, as it is related to the harmful effects of ultraviolet radiation.

Thalassotherapy, when carried out a controlled manner by physicians, is a very valuable way of preservation of health - it accelerates biological regeneration - so essential to maintain health of those living in a technological civilization. It is also irreplaceable in the supplementary treatment of various diseases harassing modern man.

\section{The scope of activity and use of the health resort base}

Health resort and the related tourism is a particularly important element of the development strategy of health resort municipalities. Generally, health tourism prospects are correlated with the condition of Polish spas and the course of privatization of this sector. The need for economy reforms in health resort is enforced by the increasing competition of foreign investors and the need to use the enormous material and human potential which is concentrated in the Polish health resorts. Polish Spas, located in the coastal area, due to their location can be 
one of the Poland's best products. They should be the best export products, which is largely confirmed today by health resorts in Kołobrzeg, Świnoujście, Kamien Pomorski or Ustka. Continuously, for many years, Polish spa resorts stand out on the map of European spas especially by unique natural wealth of therapeutic raw materials. Our native balneotherapy has at his disposal all the necessary means of treatment to fight for human health. Today, alongside the traditional model of health resorts, many additional forms such as wellness, spa, beauty, fitness is growing rapidly. Reasons for the changes are multidimensional phenomena of civilization, including the desire for the longest possible preservation of youth, health and wellbeing. These two trends in health resort therapies, are not competing with each other. Properly selected, form a complementary service, which is the basis for the modern model of spa treatment. According to J. Szymańczak (2009) - The Chairman of the management board of the Association - "The Union of Polish Health Resorts," there is at least eight indisputable arguments to rediscover the Polish resorts, including the seaside health resort, in the broadest sense of spa tourism. The most important is that:

- In the Polish health resorts, highly specialized medical staff is working, which is unique in the world. This is supported by, among others, the fact that only in Poland, medical schools train doctors in balneology,

- most facilities meet all European requirements and quality standards and is adapted to the needs of people with disabilities,

- Polish health resort is a guarantee of quality. Spa Companies acquire international certificates. This means a high quality of services in the spa treatment,

- modern Polish health resorts, are a good compromise between the model of classical, traditional spa treatment and health tourism trend - Spa \& Wellness,

- It is worth mentioning, the economic potential of Polish health resort companies. Currently, we can talk about spas, as a prosperous businesses that support the national economy and regional development,

- The stay in Polish health resorts, offers the opportunities to improve the quality of life. The improvement after treatment is maintained, on average, for a year. Staying at the spa also helps to reduce the doses of medicines and consequently, limits their side effects,

- Polish health resorts, also the seaside resorts, not only cure - a very important aspect of their activity is health prevention and health education. Their effect is a significant reduction in getting civilizational diseases of today and the decrease in mortality within a population,

- Health resort treatment is a unique product, still classical, but going with the times introduces services for health care like SPA \& Wellness..

According to the Act of 2005, health resort treatment is an integral part of the health system and is the organized business, which actions will provide health care services, carried out in the spa resort, by the health resort facilities, using the natural conditions such as:

- therapeutic properties of natural resources,

- the healing properties climate, including thalassotherapy and subterraneotherapy and the associated physical procedures..

The therapeutic orientations (profiles) of a town, define a group of disease that are subject to treatment. All medical facilities located within the town are required to operate only in the treatment of established profiles, and must meet the conditions associated with 
the specificity of the therapeutic orientations. In the past, the individual resorts had one or two therapeutic profiles. Currently in most of them, the additional profiles were introduced, which increased significantly the scope of services provided by the resort. These trends, to a large extent, have been driven by Health Insurance Fund, and now by the National Health Fund which is contracting the health care services.

The introduction of new trend to the spa is usually due to the initiative of its management. This postulate, which is then sent to the national consultant in the field of balneology and physical medicine, should be documented by stating the conditions necessary to conduct the given profile, treatment methods and the degree of preparation of appropriate medical records. Currently, Polish resorts run 18 courses of treatment, contained within the international statistical classification of diseases and health problems ICD - 10 and largely correspond to the clinical specializations [19]. These directions / courses were approved in the Minister of Health Regulation dated 13th February 2007 (Journal of Laws No. 44, 2007, pos. 285). Treatment profiles in the various health resorts, may be subject to modification and approval by the Minister of Health, after the development of health resort conditions. For such a requirement imposes on the spa, the "Law on therapeutic resort, health resorts and health resort protection areas and health resort communities" of 28th July 2005.

At the end of 2010, on a national scale, the largest number of treatment fields had been carried out by the resorts: in Kołobrzeg (11), Świeradow Zdrój (11), Świnoujscie (10), Ciechocinek (10) and Wysowa (10). Resorts given as an example, testify the high position of the coastal health resorts, in the field of health resort treatment (Table 2). It should be emphasized that Kolobrzeg belongs also to the health resort district with the largest number of centers in Poland, which at the end of 2010 had 27 centers. The second place in this regard was held by Ciechocinek - 22 centers. Health resort treatment is an integral part of the health care system in Poland. The following types of facilities of health resort treatment operated in the years 2000 - 2010, in six coastal spas: spa hospitals, sanatoriums, physiotherapeutic facilities and health clinics. Among the stationary health resort treatment facilities, there were centers for children in Kołobrzeg and Dąbki. In $2010 \mathrm{r}$, in the spa facilities in these two places stayed 7.6 thousand people ( $49.0 \%$ of the national level) under the age of 18. In Dabki, were treated with 5.1 thousand of minors, while in the spa hospital in Kolobrzeg on the treatment there were 2.5 thousand of children.

\section{The significance of the coastal resorts in the therapeutic and tourist potential of the country}

The undeniable confirmation of the importance of six statutory resorts located on the Polish coast, is the fact that at the end of 2010, not only they had a broad therapeutic profile, but also they had a total of 9630 beds in a spa treatment facilities [1]. This represented 25.5\% of the total number of beds in medical facilities throughout the country.

Table 2. Guidelines for Treatment of Polish Baltic seaside health resorts in 2010.

\begin{tabular}{|c|c|c|c|c|c|c|}
\hline Specification & Świnoujście & $\begin{array}{c}\text { Kamień } \\
\text { Pomorski }\end{array}$ & Kołobrzeg & Dąbki & Ustka & Sopot \\
\hline orthopedic - traumatic illness & $\mathrm{x}$ & $\mathrm{x}$ & $\mathrm{x}$ & $\mathrm{x}$ & $\mathrm{x}$ & $\mathrm{x}$ \\
\hline
\end{tabular}




\begin{tabular}{|l|c|c|c|c|c|c|}
\hline the nervous system injuries & $\mathrm{x}$ & $\mathrm{x}$ & $\mathrm{x}$ & $\mathrm{x}$ & \\
\hline rheumatological illnesses & $\mathrm{x}$ & $\mathrm{x}$ & $\mathrm{x}$ & $\mathrm{x}$ & $\mathrm{x}$ & $\mathrm{x}$ \\
\hline $\begin{array}{l}\text { Cardiovascular and } \\
\text { hypertension illness }\end{array}$ & $\mathrm{x}$ & $\mathrm{x}$ & $\mathrm{x}$ & $\mathrm{x}$ & $\mathrm{x}$ & $\mathrm{x}$ \\
\hline upper respiratory tract illnesses & $\mathrm{x}$ & & $\mathrm{x}$ & $\mathrm{x}$ & $\mathrm{x}$ & \\
\hline lower respiratory tract illnesses & $\mathrm{x}$ & $\mathrm{x}$ & $\mathrm{x}$ & $\mathrm{x}$ & $\mathrm{x}$ & $\mathrm{x}$ \\
\hline diabetes & & & $\mathrm{x}$ & & & \\
\hline obesity & $\mathrm{x}$ & & $\mathrm{x}$ & & & \\
\hline $\begin{array}{l}\text { endocrine illnesses / endocrine } \\
\text { disorders }\end{array}$ & $\mathrm{x}$ & & $\mathrm{x}$ & $\mathrm{x}$ & $\mathrm{x}$ & \\
\hline osteoporosis & $\mathrm{x}$ & & $\mathrm{x}$ & & & $\mathrm{x}$ \\
\hline skin disorders & & $\mathrm{x}$ & & & \\
\hline
\end{tabular}

Source: Health resort treatment in Poland in the years 2000 - 2010. Information and statistical studies. Central Statistical Office, Statistical Office in Krakow, Krakow 2011, own elaboration

Another important measure, which indicates a huge potential located on the coast of spa treatment facilities, is the total number of spa visitors staying there, which in the same year amounted to 161970 individuals, representing $28.3 \%$ of people benefiting from the spa treatment centers across the country. The obtained source materials clearly shows that most patients - health resort visitors use of spa treatment centers, which are located in Kolobrzeg (Table 3). In 2010, from the services of Kołobrzeg spa facilities benefited 104 396 people, representing $64.4 \%$ of those residing in treatment in the coastal resorts. Such a large number of health resort visitors staying in Kolobrzeg, is closely connected with some of the rich natural resources of medicinal materials, based on which, beside the sea bioclimate, the local spas have developed. A very valuable medicinal raw material, are rich sources of brine. These are strongly mineralized chloride - sodium, bromide, iodine, boron and ferruginous waters. Another natural medicinal raw material is mud, type low, which has a high biological activity and very good medicinal properties.

Table 3. Basic data on the coastal resorts, in relation to the national quantity in 2005 and 2010

\begin{tabular}{|c|c|c|c|c|}
\hline Specification & $\begin{array}{l}\text { beds in total as of } \\
\text { December } 31 \text { st }\end{array}$ & $\begin{array}{l}\text { stationary health } \\
\text { resort visitors }\end{array}$ & $\begin{array}{l}\text { one-day stays } \\
\text { in thousands }\end{array}$ & $\begin{array}{l}\text { the medical } \\
\text { treatments in } \\
\text { thousands * }\end{array}$ \\
\hline \multicolumn{5}{|l|}{ Total in Poland } \\
\hline 2005 & 35344 & 550789 & 9315,9 & 30698,9 \\
\hline 2010 & 37760 & 572882 & 10010,8 & 30244,5 \\
\hline \multicolumn{5}{|l|}{$\begin{array}{l}\text { Coastal medicinal } \\
\text { establishments }\end{array}$} \\
\hline total 2005 & 7327 & 117918 & 1906,8 & 5551,3 \\
\hline 2010 & 9630 & 161970 & $2,467,5$ & 7568,1 \\
\hline \multicolumn{5}{|l|}{\begin{tabular}{|l} 
including: \\
\end{tabular}} \\
\hline Kołobrzeg 2005 & 4561 & 84458 & 1233,4 & 2953,0 \\
\hline 2010 & 5966 & 104396 & 1496,7 & 3127,1 \\
\hline
\end{tabular}


ISSN 2078-6441. Вісник Львівського університету. Серія географічна. 2013. Випуск 43. Ч. 1.

\begin{tabular}{|r|r|r|r|r|}
\hline Świnoujście 2005 & 934 & 14721 & 266,7 & 674,1 \\
\hline 2010 & 1257 & 21842 & 330,1 & 2448,8 \\
\hline Ustka 2005 & 635 & 8215 & 160,2 & 430,5 \\
\hline 2010 & 656 & 9246 & 179,9 & 442,1 \\
\hline Dąbki 2005 & 698 & 4496 & 93,7 & 359,7 \\
\hline 2010 & 799 & 14155 & 195,2 & 383,1 \\
\hline & 319 & 4472 & 95,4 & 427,5 \\
\hline Kamień Pomorski 2005 & 456 & 5406 & 106,3 & 366,2 \\
\hline 2010 & 180 & 2056 & 57,4 & 706,2 \\
\hline Sopot 2005 & 496 & 6925 & 159,3 & 800,0 \\
\hline 2010 & & & & \\
\hline
\end{tabular}

* the medical treatments include the year 2009

Source: Health resort treatment in Poland in the years 2000 - 2010. Information and statistical studies. Central Statistical Office, Statistical Office in Krakow, Krakow 2011, own elaboration

Świnoujscie and Dąbki are valuable health resorts among the seaside spas, taking into consideration the number of beds in the spa facilities and the number of patients admitted. Świnoujście, famous for the most beautiful beach on the Baltic Sea, located on the edge of the north-western Polish, on the islands, on both sides of the river Świna is one of the most attractive cities of the Polish coast. Very characteristic for this seaside resort, is the presence of sea spray in the air, the cool sea breezes in summer and high relative air humidity. In the case of Dąbki, located on the spit between the Baltic Sea and Lake Bukowo, the main advantage is the favorable microclimate, charming nature, vast areas of forest full of unique coastal fauna and flora, mud meadows, golden beach, a beautiful lake and comforting tranquility.

In 2010 the spa treatment facilities located on the Polish Baltic coast, performed a total of 7561.1 thousand of medical treatments, which is more than $25.1 \%$ of the total number of treatments that has been done at the same time across the country (Table 3 ). This phenomenon, confirms the high rank which the Baltic sanatoriums, play in the therapeutic health resort field, on a national scale.

In our opinion, as positive phenomenon, should be also recognized, that in the past six years, there was a progressive increase in the number of places in sanatoriums and medicinal institutions. A certain exception was the spa hospitals, in which, quite significantly, decreased both the bed capacity and the number of people using the services of these institutions (Table 4). This applies both to institutions located in the coastal resorts as well as throughout the country. Compared with December 2000, across the country there was a decrease in the number of beds in such hospitals by $11.6 \%$, while in the coastal resorts up to $16.3 \%$. This situation can be explained by the combination of various circumstances, including making the reorganization of the financing of medical services, including spa stays in hospitals, for example, of people under 18 years, expansion of the base of the treatment at the domicile of people with diseases, with the 
increase in the number of non-public health care facilities, etc. Still, spa hospitals in the seaside resorts, are a significant part, both in the number of hospital beds and the number of treated individuals.

Table 4. Beds and patients in spa hospitals, in the coastal zone, in relation to the rest of the country in 2005 and 2010

\begin{tabular}{|l|r|r|r|r|}
\hline \multirow{2}{*}{ Specification } & \multicolumn{2}{|c|}{ Beds in spa hospitals } & \multicolumn{2}{c|}{$\begin{array}{c}\text { Sanatorium patients in spa } \\
\text { hospitals }\end{array}$} \\
\cline { 2 - 5 } & 2005 & 2010 & 2005 & \multicolumn{1}{c|}{2010} \\
\hline Poland & 10064 & 10002 & 144937 & 142901 \\
\hline $\begin{array}{l}\text { spa hospitals, in the coastal } \\
\text { zone, in total }\end{array}$ & 991 & 766 & 13045 & 10924 \\
\hline \multicolumn{1}{|c|}{ including: } & & & & 6912 \\
\hline Kołobrzeg & 609 & 493 & 7800 & 2258 \\
\hline Kamień Pomorski & 207 & 180 & 2484 & 1754 \\
\hline Świnoujście & 175 & 93 & 2445 & \\
\hline
\end{tabular}

Source: Health resort treatment in Poland in the years 2000 - 2010. Information and statistical studies. Central Statistical Office, Statistical Office in Krakow, Krakow 2011, own elaboration

The available source materials show that within six years $(2005-2010)$ the number of places in the sanatorium treatment facilities gradually increased. Number of beds in the analyzed health resorts has increased by $31.4 \%$, with an average $8.2 \%$ for the whole country. Relatively, the number of spa visitors staying on the treatment also increased by more than $37.3 \%$, while in the other resort treatment institutions this increase was significantly lower at around $4.0 \%$. Very clearly, in a seaside spa institutions, the number of one-day stay has increased by over $23.1 \%$ of 1906.8 thousand in 2005 to 2467.5 thousand in 2010 , with an average of $7.4 \%$ in the remaining 38 spas across the country [14]. Significantly higher rate of the increase in the number of health resort visitors, rather than one-day stay in the Baltic spas, shows that the average length of stay in the health resort center declined. This fact, as shown by results of studies conducted in selected spas of Swinoujscie and Kolobrzeg (Rydz 2005, 2012), can be explained on one hand, by the increasing popularity of a few days (often weekend) stays, offered by the health resorts, not only with a variety of therapeutic treatments strictly, but also SPA \& Wellness. On the other hand it can be expalained by a substantial share of the total number of foreign spa visitors, mainly from Germany and Scandinavia. Foreign spa guests, mostly prefer a two-week stays. Based on the research that was conducted, we observe that in 2010 out of the total number of 42205 foreign spa visitors staying in the Polish health resorts, 26.2 thousand of them (which is about $62.0 \%$ ), chose Kolobrzeg as the main place of staying. The foreigners constituted $26.9 \%$ of all patients staying on treatment in Kolobrzeg.

A large group of foreign spa visitors - mainly from Germany - benefited from the treatment and preventive care in Swinoujscie. In 2010, it consisted of approximately 8.4 thousand of people. Among all persons using the spa facilities of Swinoujscie, foreigners constituted $38.5 \%$ of patients. Noteworthy is the fact that sanatoriums, located on the Polish coast, were visited by a considerable number of patients who bear the full pay for the stay. In 2010, they accounted for approximately $45.0 \%$ of the total number of fully paying patients in the country. 
It also indicates, in our opinion, the quality of services provided by these institutions.

The study, which was conducted in sanatorium "Węgiel Brunatny" in Kolobrzeg in 2005 and sanatoriums "Bałtyk" and "Bursztyn" in Swinoujscie in 2011, shows that visitors from Germany and Scandinavia, were very positive about their stay, both in Kolobrzeg, as and Świnoujście (Rydz 2005, 2012). The greatest strengths included: air quality, natural sandy beaches, coastal dunes and beautiful wildlife. The high recognition among the spa visitors, aroused: bioclimate medicinal properties and anthropogenic values occurring. Spatial configurations of health - leisure districts and their incorporation into urban systems also gained a recognition among foreign spa visitors. Also very positively were rated not only health services but also service and gastronomic outlets.

The potential of coastal resorts also lies in a large number of naural medicine procedures performed, which include mineral baths, baths $\mathrm{CO} 2$, mud and inhalation treatments. Above presented conditions, resulting from the natural environment and the base premises, fully confirm that these treatments are the branded product of the presented spas. This is proven, not only by about $20 \%$ share in total number of treatments provided by the spa treatment facilities, but also by steadily increasing demand for traditional - natural medicinal materials, which the patients able to receive them, trust the most. In terms of number of naural medicine procedures performed, definitely at the forefront are the health resort facilities in Kolobrzeg (57.5\% of the total number performed in 2010) and Świnoujście $(15 \%) . \mathrm{n}$ the other four resorts: Kamien Pomorski, Dabki, Ustka and Sopot, the share was much smaller. On average, for one person staying in the seaside resorts of treatments, there were about nine naural medicine treatments. The research shows that both the quantity and

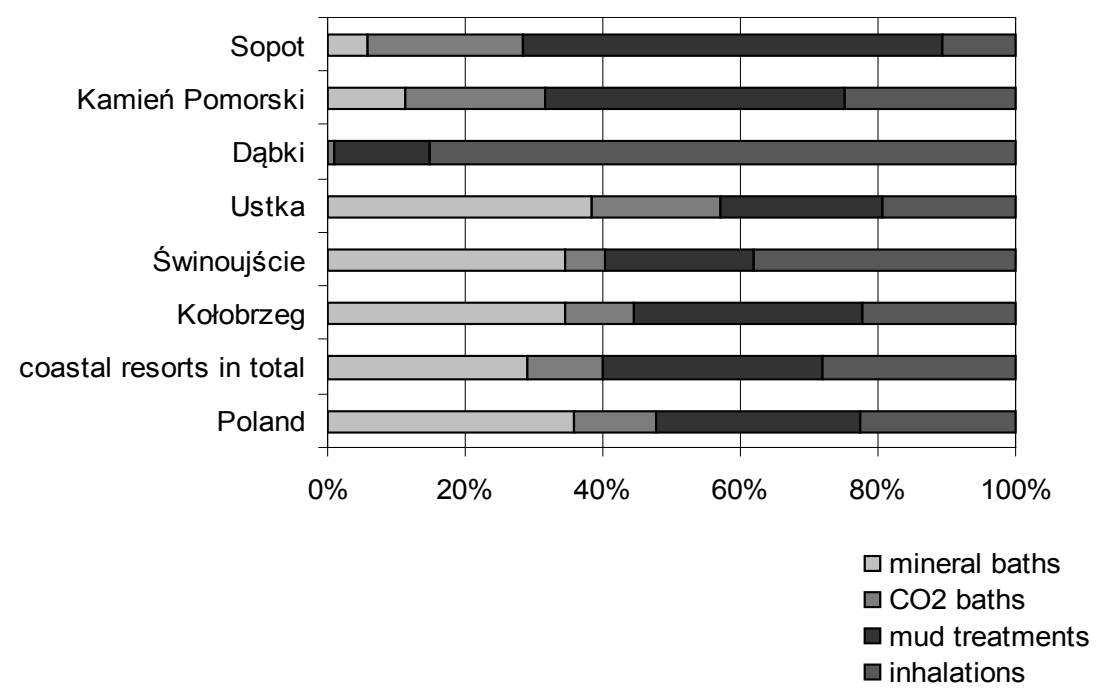

structure of the naural medicine treatments offered by spas is varied (Table 5 and Fig. 2).

Figure 2. The structure of natural medicine treatments in the coastal health resorts in relation to Poland in 2010.

Source: Health resort treatment in Poland in the years 2000 - 2010. Information and statistical studies. 
Central Statistical Office, Statistical Office in Krakow, Krakow 2011, own elaboration

This is, among others, related to the medicinal raw materials, which are most available in the various spas and facilities to enable their use in spa therapy. The most common natural procedures performed in these spas, are mineral baths - especially in Kolobrzeg, Świnoujście Ustka as well as mud treatments, which are predominant in the case of spas in Kamien Pomorski and Sopot. Noteworthy is the youngest spa in Dąbki, that due to the specific location of the village: by the open sea, at the shoreline protruding slightly into the sea - has a very favorable sea climate, supporting the treatment of respiratory diseases and allergies occurring in pediatric patients and adults. Therefore, inhalation treatments represent more than $85.0 \%$ of the total number of naural medicine treatments provided for patients in the spa.

Table 5 Users of natural medicine treatments in coastal resorts in relation to the rest of the country in 2010

\begin{tabular}{|c|c|c|c|c|c|c|}
\hline \multirow[b]{2}{*}{ Specification } & \multirow{2}{*}{$\begin{array}{c}\text { Users of } \\
\text { natural } \\
\text { medicine } \\
\text { treatments }\end{array}$} & \multicolumn{5}{|c|}{ Natural medicine treatments } \\
\hline & & in total & $\begin{array}{c}\text { mineral } \\
\text { baths }\end{array}$ & $\mathrm{CO}_{2}$ baths & $\begin{array}{l}\text { mud } \\
\text { treatments }\end{array}$ & inhalations \\
\hline $\begin{array}{l}\text { Poland } \\
\text { in thousands }\end{array}$ & 594,2 & 6452,2 & 2306,9 & 769,0 & 1915,6 & 1460,8 \\
\hline in $\%$ & & 100,0 & 35,8 & 11,9 & 29,7 & 22,6 \\
\hline $\begin{array}{lr}\text { coastal resorts in } \\
\text { total } \\
& \text { in } \\
& \text { thousands }\end{array}$ & 171,5 & 1433,0 & 415,7 & 155,4 & 459,6 & 402,3 \\
\hline in $\%$ & & 100,0 & 29,0 & 10,8 & 32,1 & 28,1 \\
\hline including: & & & & & & \\
\hline $\begin{array}{l}\text { Kołobrzeg } \\
\text { in thousands }\end{array}$ & 105,2 & 816,1 & 278,4 & 81,7 & 272,1 & 177,9 \\
\hline in $\%$ & & 100,0 & 34,5 & 10,0 & 33,4 & 22,1 \\
\hline $\begin{array}{l}\text { Świnoujście } \\
\text { in thousands }\end{array}$ & 26,6 & 215,3 & 74,7 & 12,5 & 46,1 & 82,0 \\
\hline in $\%$ & & 100,0 & 34,5 & 5,7 & 21,6 & 38,2 \\
\hline $\begin{array}{l}\text { Ustka } \\
\text { in thousands }\end{array}$ & 8,8 & 130,5 & 50,6 & 23,9 & 30,9 & 25,1 \\
\hline in $\%$ & & 100,0 & 38,5 & 18,5 & 23,8 & 19,2 \\
\hline $\begin{array}{l}\text { Dąbki } \\
\quad \text { in thousands }\end{array}$ & 14,2 & 109,4 & 0,0 & 1,2 & 15,2 & 93,0 \\
\hline in $\%$ & & 100,0 & 0,0 & 0,9 & 13,8 & 85,3 \\
\hline $\begin{array}{r}\text { Kamień Pomorski } \\
\text { in thousands }\end{array}$ & 7,8 & 44,7 & 5,0 & 9,0 & 19,6 & 11,1 \\
\hline in $\%$ & & 100,0 & 11,3 & 20,4 & 43,3 & 25,0 \\
\hline $\begin{array}{l}\text { Sopot } \\
\text { in thousands }\end{array}$ & 8,9 & 122,9 & 7,0 & 27,1 & 75,7 & 13,2 \\
\hline in $\%$ & & 100,0 & 5,7 & 22,5 & 61,1 & 10,6 \\
\hline
\end{tabular}

Source: Health resort treatment in Poland in the years 2000 - 2010. Information and statistical studies. 
Central Statistical Office, Statistical Office in Krakow, Krakow 2011, own elaboration

The strong primacy of Kolobrzeg, in the performing of natural medicine procedures is directly linked to rich sources of brine. These are highly mineralized chloride - sodium, iodine, bromide waters, which improve improve blood circulation in the skin and make it easier to cleanse the body of toxins. Another natural medicinal raw material commonly used in this town, is a therapeutic mud - type low, which has a high biological activity and very good medicinal properties. In Kołobrzeg resort, different forms of healing are conducted: spa hospital for adults and children, sanatoriums and spa treatment. All facilities operated by Spa Kolobrzeg are located in the resort area in the immediate vicinity of the beach and the seaside park preserved in a natural state.

The mild stimulus seaside climate, a rich source of highly mineralized brines, own peat deposits, a wide, natural sandy beach (the most beautiful on the Baltic Sea), coastal dunes and the beautiful wild nature and the good infrastructure of treatments, are the main advantages of the second largest resort on the Polish coast. The long tradition and wellestablished brand of Świnoujście as a spa give assurance that the time spent in the resort will be pleasant and rewarding. Based on the specific conditions of the microclimate and natural materials therapeutic treatment, a range of 10 various directions is carried out here (see Tab. 2). The Spa in Świnoujscie, as already mentioned, stands out not only in relation to the resorts located on the coast, but also to the rest of the country, by a considerable number of foreign health resort visitors using the spa treatment as well as tourists. The significant impact on this phenomenon has, among others, the fact of favorable location (close to the western border). These ties have become especially close, after Polish fuller integration with European Union countries.

The third largest resort in the Polish Baltic zone, taking into account the number of seats in a sanatorium, stationary health resort visitors, as well as patient days, are Dąbki. The indisputable strengths of this small town are: the specific location of the open sea, the coastline protruding slightly into the sea, charming nature, vast areas of forest full of unique coastal fauna and flora, golden beach and comforting tranquility. Dąbki, mainly used in supporting treatment of respiratory diseases and allergies, are located in the coastal climate zone, strongly affecting the human body, subdued by forests, and proximity to a large lake Bukowo. This is, among others, confirmed in a structure performing of the treatments (Fig. 2). Generally, the treatment in a six main courses is carried out here (see Tab. 2).

Ustka also belongs to the major seaside resorts in the country. The undeniable value of this part of the coast is strongly, but unspecifically, interacting climatic stimuli. Ustka lies directly in the impact zone area of the Bornholm Deep in the Baltic Sea, which accounts for the high variability of temperature, the wind direction and strength. The result is a high concentration of marine aerosol in the air, a significant concentration of iodine and other trace elements and macro elements. The location of the spa and climatic conditions make Ustka ideally suited to carry all-year-round treatment. Based on climatic conditions, natural resources and appropriate medical treatment facilities - spa resort specializes in the seven fields of medicine, among others: neurological disorders, orthopedic and rheumatic diseases, respiratory and metabolism (see Tab. 2). Those are both physiotherapeutic treatments, as well as those from the scope of electrotherapy, physiotherapy and massage. 
The treatment in a spa is: to relax physically, to use medical treatments, it is about application of appropriate therapeutic diets and the climate effect.

A significant function of the spa, due to its location in more than one million citizen agglomeration of Gdansk, is met by Sopot. Getting by this resort in 1999, the status of the spa, legally sanctioned previously (since 1823), conducted medical activities by using the marine climate and mineral springs. After obtaining municipal rights in 1901, Sopot became one of the most popular places on the Baltic. The resort visitors have given the name to the city. They started to call it - the Riviera of the North and the Baltic Pearl. From the beginning, Sopot became a fashionable place. Those hungry for relaxation and rest and often in need of an artistic inspiration, were coming numerously to Sopot. Both, existing climatic characteristics of the coast, the base of santorium treatment and healing occurring in natural materials results in performing the five medicinal fields in sanatorium (see Tab. 2). In terms of natural medicine treatments a lot of mud or $\mathrm{CO}_{2}$ baths is performed (Fig. 2) also procedures in physiotherapy and electrotherapy are being implemented.

The smallest, in terms of places of residence in a sanatorium facilities, is a health resort in Kamien Pomorski. It is located along the coast of Szczecin and has excellent climatic conditions favorable to biological regeneration and rejuvenation. The origins of the spa in Kamien Pomorski reach the nineteenth century, when the rich sources of healing waters were discovered. The nearby deposits of peloids, attractive geographic location and specific microclimate caused that the city began to take on the nature of the therapeutic-recreation center and in 1967 it obtained the status of a spa. Spa in Kamien Pomorski operates with 5 main therapeutic orientations (see Tab. 2). The leading therapeutic spa specialties include: the early orthopedic rehabilitation, the treatment of cardiovascular diseases - including the early cardiological rehabilitation and the treatment of the locomotor system resulted from orthopedic reasons - trauma, neurological and rheumatic. In the process of healing and rehabilitation, the spa takes advantage of the natural medicinal materials in the form of iodide - bromide - chloride brine and their own rich deposits of peloid.

Seaside health resorts play an important role in the treatment of children and adolescents under the age of 18 . It should be remembered that the concern for the future of society must begin with the health care of children. The available reports of experts, clearly state that Poland shows a growing number of cases of respiratory system diseases, diabetes, and more recently - obesity, type 2 [11]. Spa treatment fits perfectly in the system of healing and prevention. Well-planned and carried out allows to improve the health of children. However, it is more expensive than the treatment of adults. Children must be ensured with round the clock care - both medical and tutorial. In the recent years, this resulted in a reduction of the number of spa hospitals for children, because, in terms of commercial law companies, it is difficult to keep loss-making facilities. The confirmation of this is the fact that while in 2005 children and adolescents under 18 years accounted for approximately $16.0 \%$ of patients staying in hospitals, which makes a group of 23.2 thousand of people staying Polish spas, whereas in 2010, a group of minors treated in all hospitals was 15.4 thousand in total, while their share in total number of patients dropped to $10.8 \%$ [14].

Dąbki and Kolobrzeg, situated on the coast of the spa, play an important role, on a national scale, in the treatment of minors. In 2010 in spa facilities of those two locations, there were a total of 7.6 thousand of minors staying for the treatment, which represents 
$49.0 \%$ of the national number. It should be emphasized that in Dąbki, on medicinal treatment, in 2010, there were 5.1 thousand of people under the age of 18. For comparison, in the largest medical institutions of this kind in Poland - Rabka Zdrój, in the same period of time, there were 6 thousand children. Spa complexes for minors, located in Dąbki, specializes in the treatment of upper and lower respiratory tract (respiratory medicine, ENT) of children aged 3-7 years residing under adult supervision.

Much longer tradition in the field of specialized health resorts, for people under 18 years of age, has Kołobrzeg. Already in the early 60's of the last century, the treatment of children on a large scale have been taken in the Children's Spa Hospital - "Słoneczko", and health resort hospital "Muszelka". Currently, for 27 - day stays, the hospital "Słoneczko", admit children with disorders of the upper and lower respiratory tract disease, diabetes, skin diseases (especially allergic) and the pathology of recent years - obesity. Apart from clinical treatment, physical procedures are used, in the permitted extent as well as children's developmental and therapeutic gymnastics. Spa Hospital in Kołobrzeg, specializing in treatment of children, in 2010 accepted more than 2.5 thousand patients, that is $31.4 \%$ of minors treated in the Baltic spas.

The potential of Polish seaside resorts, next to a significant share in the performance of natural medicine treatments also lies in a large number of other treatment services performed on a national scale for the treatment of people staying in the health resorts. The biggest number of them was performed in the field of hydrotherapy - 556.8 thousand, which gives $35.8 \%$ of the total number of such procedures performed in the medical facilities on a national scale. There has been a significant part of these spas in the implementation of electrotherapy treatments $(24.6 \%$ of the total number of such procedures in the country), phototherapy (22.5\%), physiotherapy (16.7\%) and treatments grouped as "other" $(55,9 \%)$ [14].

In the coastal area, on the Polish coast, based on the rich natural assets with medicinal properties and the specific climate, not only presented the statutory spas were build, but also the holiday and rehabilitation centers (Jastrzębia Góra, Jastarnia, Jarosławiec) and towns which provide selected health services in the field of preventive health (Łuków, Łeba, Dźwirzyno, Dziwnówek) (Fig. 1). The research that was conducted shows that people in villages acting as holiday-rehabilitation resorts benefit from wellness cabinets, whirlpool, water jets, a variety of purely therapeutic treatments as well as SPA \& Wellness. The offer of SPA \& Wellness treatments, is sometimes very rich. For example, Ustka Hotel "Lubicz" has an offer in the form of well-designed packages that are addressed to different groups of tourists. An example would be a "Feminine Style", "A Guy Thing" and "The Power of the ocean - a package for Vitalizing Gentlemen ". These packages, beside accommodation, food and organized attractions, include specially prepared offer of beauty and medicine treatments. The study shows that several coastal municipalities launched a new-type resorts SPA \& Wellness. The vanguard in this field, leads Rewal municipality (6 new objects). Also in the traditional sanatorium towns, more and more commercial accommodation facilities are created, using the reputation of the spa and operating on the basis of a wide range of health packages of the SPA\& Wellness type.

Unlike a traditional spa treatment, focusing on patients' rehabilitation, often chronically ill, or who are post-surgery, the SPA \& Wellness offer is based on the "philosophy of wellbeing" and puts a strong emphasis on wellness, fashion, fitness and emotional harmony of 
$\operatorname{man}[18]$.

Establishments operating in the health resort spas are offering to their guests: accommodation services, food, medical treatment and medical care. It should be noted, however, that more and more people coming to the spas are not patients of medicinal facilities. Spas attract visitors with previously discussed qualities of the natural environment, the climate, but also with the ability to use various types of equipment such as mineral water fountains, graduation towers, spa park etc. Artistic events organized there, improve the visual quality of a stay of tourists in spas, they are often of a serious rank such as: the International Music Festival, Summer of Operetta in Swinoujscie or Jazz Festival, International Folk Meetings and the International Festival "Music in the Cathedral" in Kolobrzeg and many others.

To illustrate the size of spa tourism Poland following assumptions were made [14]:

- It was concluded that the main purpose of the journey, of all tourists coming to the towns in the spa municipalities, were the qualities associated with broadly understood health condition.

- The data about collective tourist accommodation establishments and the number of tourists using them in the spa municipalities was presented

- Factors calculated per 100 inhabitants, are presented for individual voivodships.

In light of these assumptions, it is confirmed that the largest number of beds in collective tourist accommodation establishments, per 100 inhabitants, was in the spa municipality of Silesian voivodship - 28 (with the voivodship average of 1 ) and the coastal regions: the West Pomeranian - 20 (with the voivodship average of 6) and Pomeranian - 16 (with the voivodship average of 4 ).

Generally, tourist facilities in the municipalities of the spa, was better developed than the national average and the average in each province (Fig. 3).

In 2010, the number of beds in collective tourist accommodation establishments per 100 residents, on average, across the country was 2 , while in spa municipalities -12 . In almost all voivodships, the intensity indicator of beds in relation to population was higher in the spa municipalities, than the average in the region. It should be added that, in comparison to 2005 , in 2010 , there has been an increase of accommodations by $8.3 \%$ (while the average in the country has increased by $7.1 \%$ ) in collective tourist accommodation establishments, in spa municipalities. Very clearly, in the same period, the bed capacity in hotel facilities also increased.

Relatively, Poland has also increased the number of accommodated in relation to the population in 2010 and it was 54 per 100 inhabitants. A similar index calculated for spa municipalities was 279 , which is five times more than on the national scale. In case of coastal communities located in Pomerania and the West Pomerania provinces, the rate was much higher (Fig. 4). It is, among other things, the result of constantly expanding hotel base, as well as other collective accommodation establishments. Classic example of this is a city and municipality Ustka, in which, in recent years, such objects as: "Trojanowski" Hotel, "Rejs" Hotel or "Royal Baltic Luxury Boutique" Hotel, were built, as well as "Columbus" Hotel and "Kormoran Wellness Medical SPA" Hotel in Rowy. The intensity indicator of the number of people accommodated in collective tourist accommodation 


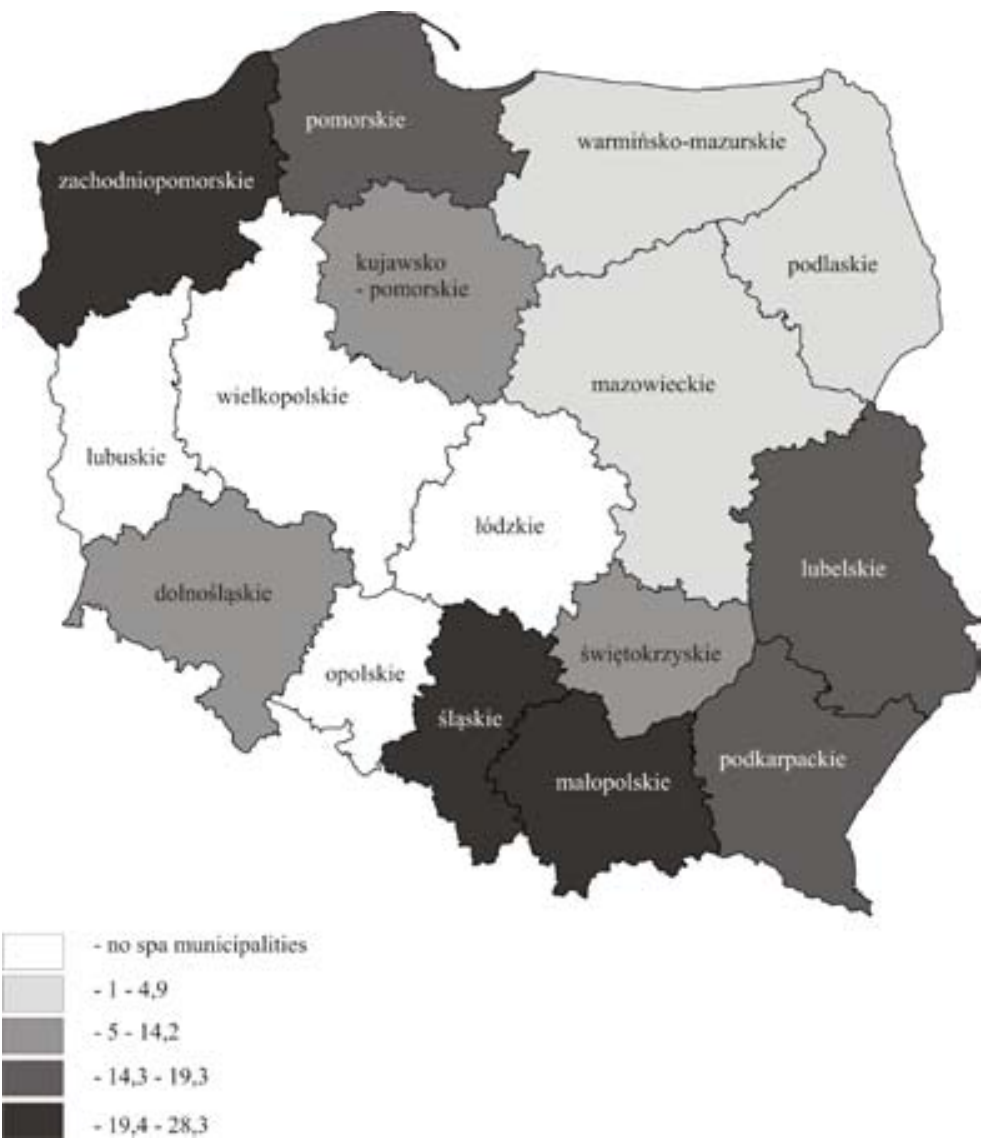

Figure 3. Beds in collective tourist accommodation establishments in spa municipalities, per 100 inhabitants, by provinces in 2010 .

Source: Health resort treatment in Poland in the years 2000 - 2010. Information and statistical studies. Central Statistical Office, Statistical Office in Krakow, Krakow 2011, own elaboration

establishments in the municipalities of spas, was 25 times higher than the average in the region[14]. Another characteristic feature of tourism in coastal communities is a relatively long period of staying of tourists, who, apart form enjoying the charms of natural and anthropogenic environment, are also trying to use, depending on the availability, medicinal properties of spas.

Today, for the majority of tourists traveling to improve their health, standard of accommodation services is becoming increasingly important. The confirmation of this, is the creation of a number of hotels in the Polish seaside health resort communities with a high standard such as "Hampton" Hotel by Hilton and "Interferie Medical SPA" Hotel in Świnoujście, "Aquarius SPA" Hotel and "Sand" Hotel in Kolobrzeg or "Sheraton Hotel Conference Center \& Spa" in Sopot.

Polish seaside resort are a significant attraction for visitors from the country but also from abroad. The interest in such a way of spending free time is increasing, therefore, spas 


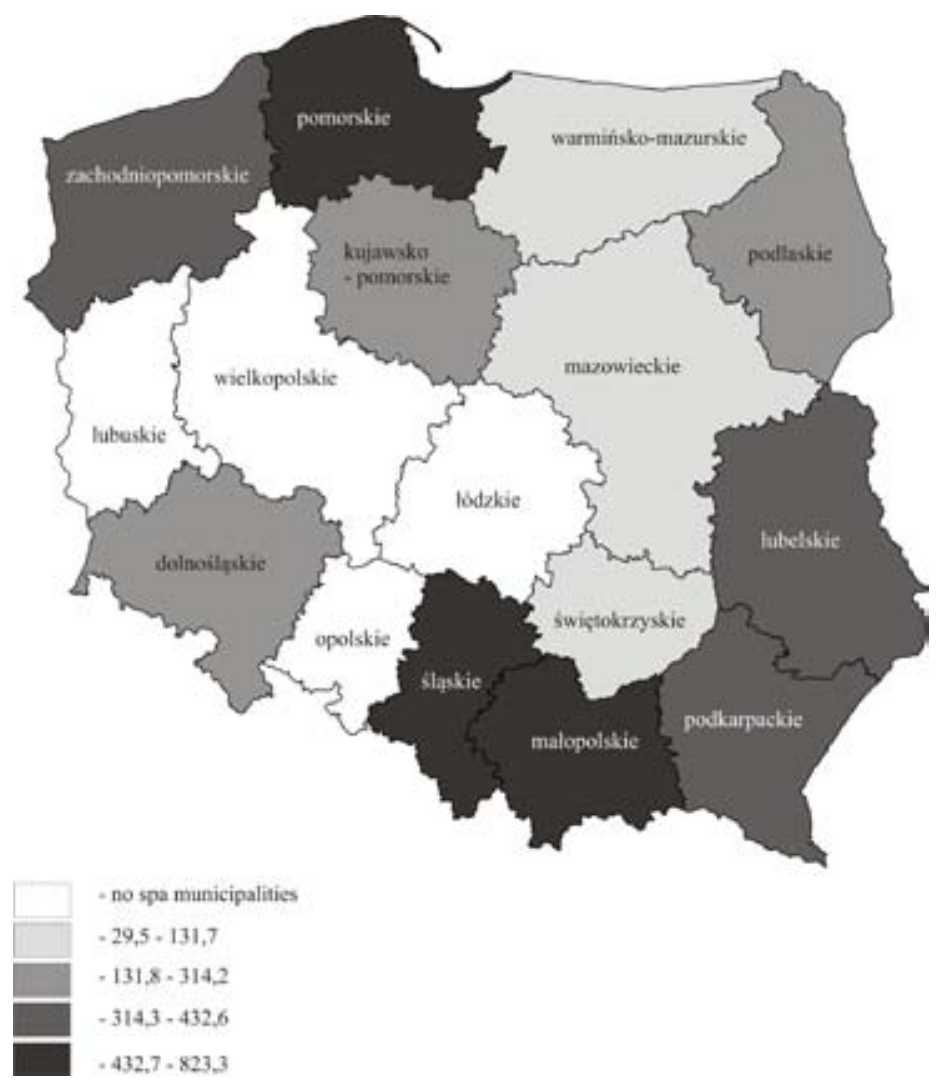

Figure 4. Users of accommodation in collective tourist accommodation establishments in spa municipalities, per 100 inhabitants, by provinces in 2010 .

Source: Health resort treatment in Poland in the years 2000 - 2010. Information and statistical studies. Central Statistical Office, Statistical Office in Krakow, Krakow 2011, own elaboration

have prospects for further development. Moreover, in the Polish coastal zone, there are eight places (see Fig. 1) with appropriate climatic and environmental resources that could potentially acquire the status of the spa.

\section{Concluding Remarks}

Deliberations presented in the report, drew attention to the tourist attractiveness of the Baltic the Polish health resorts by assessing natural and non-natural factors of their development. This was done by assessing the role that coastal resorts, play in the provision of treatment services across the country. Also, the fact that the health resorts and health tourism have converging areas of development, was taken into account. The first one refers to a wide range of human wellness through the use of medicinal waters, natural minerals and climate characteristics. The second one is active leisure through the usage of services like spa, wellness, beauty and similar services. Such people, expect instant effects of treatment and rest, as well as rapid regeneration, often during the short weekend stays. The growing demand for health tourism also results from the fact that women more frequently 
making decisions on tourist trips, usually to places where the family and they themselves can not only meet the needs of recreation and physical activity during these trips.

The above considerations, the survey results, own observations of the spas market, taking into consideration the conditions of functioning of the market in Poland, all this allows to formulate some comments. The rich natural values of medicinal properties, the presence of mineral springs and unique microclimate mean that health resorts located on the Polish coast play a very important role in the provision of specialized services for people coming from various health ailments, including young people under 18 years old. Polish seaside resorts are more and more willingly visited by foreigners for example from Germany or from the Scandinavian countries, which also reflects well on the quality of the local services.

Considering the Polish society in the years $1950-2010$, it is clear that since the second half the 90 s of the twentieth century, there is not only a decrease in population in our country, but the phenomenon is accompanied by a gradual lengthening of life expectancy. In 2010, the average life expectancy for men in Poland was 71.4 years and 80.1 years for women. Significant progress in extending the average life expectancy, should be assigned to extensive promotion of healthy lifestyles, including the use of broadly defined health tourism. Satisfactory, it seems in this context, the fact that the Polish health resorts, including the seaside ones, are increasingly being visited by the commercial spa visitors. This group, composed predominantly of people aged 45 -65 years, are people more prosperous in material terms, to put it simply. In this context the question arises concerning the progressive privatization of spas. Would it not reduce the services of health resorts, for people less wealthy or / and older, as indicated by permanently extending, already long, waiting periods for referral to National Health Protection Fund refunded sanatoriums.

Spa treatment activities are connected, as shown by the results of research, with the problems of social, political, economic, medical and cultural fields of interests as well with spatial planning. It has a large impact on regional development, in particular, a positive effect on employment growth. Therefore, in the spa municipalities, is hidden an enormous economic potential.

Spa and health care tourism, constitutes an important segment of tourism in the coastal region, due to the relatively short tourist season. It is a chance to extend the same season, even for the entire year, which ensures the rational use of the entire tourism infrastructure by raising economic efficiency, maintenance of resources and ensuring year-round employment for large numbers of local people.

\section{LIST OF REFERENCES}

1. At the end of 2010, the status of health resort in Poland - in accordance with the Act of 28 July 2005 on treatments provided by spa, spas and health resort protection areas and spa communities - had 44 locations. In this figure, there were six places from the Polish coast Swinoujscie, Kamien Pomorski, Kolobrzeg, Dąbki, Ustka and Sopot. For: Health resort in Poland in the years 2000 - 2010, Central Statistical Office, Statistical Office in Krakow, Krakow 2011

2. Durydiwka M., 2005, Differentiation of the development of tourism and recreational functions in health resorts /IN:/ Development of tourist, recreational and sporting functions 
in health resorts, Edited by E. Rydz, Pomeranian University in Słupsk, Słupsk, pp. 46-59

3. Jackowski A., 1981, Functional typology of tourist destinations (based on the example of Nowy Sącz region), Published by Jagiellonian University, Cracow

4. Januszewska M., 2002, The importance of spa products in the development of tourism in Poland", Scientific Journals “Economic Problems of Tourism”, No. 2, Publisher - University of Szczecin, Szczecin, pp. 22-23

5. Jażewicz I., 2005, Ustka as a center for health tourism, Development of of tourism in health resorts, Edited by E. Rydz, Pomeranian University in Słupsk, Słupsk, 2005, pp. 60 - 70

6. Kaczmarek J.i in., Produkt turystyczny albo jak organizować poznanie świata („A tourist product or how to organize the cognition of the world"). Wydawnictwo Uniwersytetu Łódzkiego, Łódź, 2002, s. 22

7. Kowalczyk A., 2005, Nowe formy turystyki miejskiej, „prace i Studia Geograficzne”, z. 35, Zmiany przestrzenne i funkcjonalne obszarów miejskich, edited by A. Lisowskiego, Faculty of Geography and Regional Studies, University of Warsaw, Warsaw, pp.155 - 173

8. Koztowska B., 2009, The climatic conditions of health resorts /IN:/ The great book of Polish spas, seaside resorts and places with spa-climatic qualities, edited by Z. Franczukowski, Published by „Mirex”, Bydgoszcz pp. 55-62

9. Kozłowska-Szczęsna T., Błażejczyk K., Krawczyk B., Limanowska D., 2002, Polish spas bioclimate and possibilities of its use in medicine, the monographs, Institute of Geography and Spatial Organization, Polish Academy of Sciences, No 3, Warsaw

10. Kruczek Z., 2009, History of Polish spas /IN:/ The great book of Polish spas, seaside resorts and places with spa-climatic qualities, edited by Z. Franczukowski, Published by „Mirex”, Bydgoszcz 2009, pp. 15-16

11. Krystosik - Easecka K., Health resort Kolobrzeg for children and youth, The patients' Newspaper No. 3 (44), 2009, pp. 12-13

12. Krzymowska - Kostrowicka A., 1999, Geoecology of tourism and recreation, Polish Scientific Publishers PWN, Warsaw

13. Leszczyki S, 1939, The development of the spa in Poland, "Polish Tourism", No 9, R. II, pp. $111-118$

14. Lecznictwo uzdrowiskowe w Polsce w latach 2000 - 2010. Informacje i opracowania statystyczne. GUS, Urząd Statystyczny w Krakowie, Kraków 2011, s. 85 - 93 („Health resort treatment in Poland in the years 2000 - 2010. Information and statistical studies. Central Statistical Office, Statistical Office in Krakow, Krakow 2011. p.85-93")

15. Liszewski S, 1988, Functions of seaside settlement in light of the analysis of tourism. Example of the Hel Peninsula, Acta Universitatis Lodziensis, „Turism”, No 4, pp. $39-67$

16. Liszewski S, 2009, Polish tourist space. The concept of tourism organizations, /IN:/ Contemporary problems of structural change of geographical space, edited by I. Jażewicz, Akademia Pomeranian University in Słupsk Słupsk, pp. 59 - 69

17. Łoboda J., 2006, Some of the social determinants and the dilemmas of modernity versus spa tourism, /IN:/ Spa tourism in the economy of the region and country, edited by T. Iwanek, Published by Higher School of Business Management, Wrocław, pp. $13-23$

18. Mika M., Ptaszycka - Jackowska D., 2007, Types of health turism, /IN:/ Turism, edited by W. Kurka, PWN, Warsaw, p. 279

19. Ponikowska J., 2009, Guidelines for Treatment of Polish health resorts, /IN:/ The great book of Polish spas, seaside resorts and places with spa-climatic qualities, edited by Z . Franczukowski,, Published by „Mirex”, Bydgoszcz pp. 170 - 171 
20. Rajman J., 1998, Urban settlement pattern during the southern Polish socio-economic transformation of the country, Academic and Scientific Annals, Wyższa Szkoła Pedagogiczna - Teachers College Cracow, z. 198, Geographical works 17, pp. 15-23

21. Rydz E., 2005, Adjustment of sanatorium treatment to the patients' needs, on the example of the "Weqgiel Brunatny" sanatorium in Kołobrzeg. Development of tourism in health resorts, Edited by E. Rydz, Pomeranian University in Słupsk, Słupsk, 2005, pp. $241-264$

22. Rydz E., 2012, Świnoujście a spa treatment center in the West Pomeranian region, /IN:/ Economic and organizational aspects of the Polish health resorts, Edited by E. Rydz, Akademia Pomeranian University in Słupsk, Słupsk

23. Straburzyńska - Lupa A., 2009, The sea treatment /IN:/ The great book of Polish spas, seaside resorts and places with spa-climatic qualities, edited by Z. Franczukowski, Published by „Mirex”, Bydgoszcz

24. Straburzyński G., 2009, Uzdrowiska - anachronizm, luksus czy konieczność, /IN:/ The great book of Polish spas, seaside resorts and places with spa-climatic qualities, edited by Z. Franczukowski, Published by „Mirex”, Bydgoszcz, pp. $21-27$

25. Szmielińska P., 2001, Tourism as a chance to reduce the level of unemployment (based on the example of the city and municipality of Ustka) /IN:/ Tourism as a factor in the development of regions, cities and rural areas, edited by W. Maik i K. Marciniak, Scientific Papers of Pomeranian University School of Tourism and Hotel Management in Bydgoszcz, No 1, pp. $83-90$

26. Szymańczak J., 2009, Introduction, /IN:/ The great book of Polish spas, seaside resorts and places with spa-climatic qualities, edited by Z. Franczukowski,, Published by „Mirex”, Bydgoszcz, pp. $8-14$

27. Szymańska $W$., 2009, The living conditions of the population of medium-sized cities in Poland, /IN:/ Contemporary problems of structural changes of geographical space, edited by I. Jażewicz, Pomeranian University in Słupsk Słupsk, pp. 300 -318

28. Warszyńska J., Jackowski A., 1978, Basics of tourism geography, PWN, Warsaw

29. Wolski J., 1978, Leisure and tourism in spas, Poznań, pp. 52-53

Стаття: надійшла до редколегї 28.05.2012 прийнята до друку 06.06.2012 


\title{
ТУРИСТИЧНА ПРИВАБЛИВІСТЬ ПОЛЬСЬКИХ КУРОРТІВ УЗБЕРЕЖЖЯ БАЛТІЙСЬКОГО МОРЯ
}

\author{
Е. Ридз, П. Шмелінська-Пстрашек \\ Інститут географії і регіональних досліджень \\ Поморський університет в Слупську \\ Слупськ, Польщиа
}

\begin{abstract}
Санаторно-курортне лікування, яке передбачає використання лікувальних властивостей кліматичних або природних ресурсів, має давні традиції у світі. 3 найдавніших часів числа пацієнти їздили в місця, які мають води, яка відрізняється від звичайної води через різні смак, запах, а іноді і тепло. Дуже популярні були місця багаті термальними джерелами, не тільки для гігієнічних цілей, але в основному для омолодження.

Ключові слова: турист, туристична привабливість, термальні джерела.
\end{abstract}

\section{ТУРИСТИЧЕСКАЯ ПРИВЛЕКАТЕЛЬНОСТЬ ПОЛЬСКИХ КУРОРТОВ ПОБЕРЕЖЬЯ БАЛТИЙСКОГО МОРЯ}

\author{
Е. Рыдз, П. Шмелинська-Петрашек \\ Институт географии и региональных исследований \\ Поморский университет в Слупске \\ Слупск, Польша
}

\begin{abstract}
Санаторно-курортное лечение, которое предполагает использование лечебных свойств климатических или природных ресурсов, имеет давние традиции в мире. С древнейших времен числа пациентов ездил в места, в которых воды, которая отличается от обычной воды через различные вкус, запах, а иногда и тепла. Очень популярны были места богаты термальными источниками, не только для гигиенических целей, но в основном для омоложения.

Ключевые слова: турист, туристическая привлекательность, термальные источники.
\end{abstract}

